\title{
Maturity for School among Pre-primary Children with Visual Impairments as Prerequisite for Successful Socialisation
}

\author{
Vytautas Gudonis ${ }^{1}$, Audrè Urbiené2 \\ 1 Šiauliai University, Faculty of Social Welfare and Disability Studies, Department of Special Education, \\ P. Višsinskio St. 25, LT-76351 Šiauliai, Lithuania, vytautas.gudonis@su.lt \\ 2 Petras Avižonis Vision Centre of Šiauliai, Papilès St. 3, LT-76196 Šiauliai, Lithuania
}

\begin{abstract}
The article presents the results of the longitudinal research on school maturity of pre-primary children with visual impairments, which was conducted from 2003 to 2013. Following the results of this longitudinal research, the problems of education of pre-primary children with visual disorders, which were determined by visual impairments and insufficient attention of educators, were identified. The article makes attempts to reveal the content of school maturity and, on the basis of the acquired research results, to prove the necessity to carry out research on school maturity of pre-primary children attending educational institutions twice a year, preparing individual recommendations after the first research.
\end{abstract}

Keywords: pre-primary children, maturity for school, visual impairment.

\section{Introduction}

The main factors, which have influence on pre-school children's socialisation, include family (parents, grandparents, senior brothers and children) and a pre-school institution (kindergartens, centres, etc.). The impact of friends is not particularly strong at pre-school age yet. A pre-school education institution is a place, where a child gets acquainted with social environment: teachers, speech therapist, psychologist and other specialists as well as peers. Since the main goal of pre-primary education is to educate and develop an active, self-confident and confident in own abilities individual, who has a strong motivation for cognition ensuring unfolding of child's personality, child's maturity for school has become 
a significant prerequisite for child's successful socialisation. Socialisation is a process, which starts in the childhood: becoming aware of norms, laws and lifestyle appropriate in the society, an individual becomes a member of the society, where the biggest influence on this process is received from the family, educational institution (kindergarten, school), peers, society and mass media (Berns, 2009; Kvieskienè, 2005). Prerequisites for successful learning at school are observed at pre-school age. Despite numerous approaches to the concept of school maturity, the majority of authors agree that the maturity for school embraces physical, intellectual, emotional and social indicators of pre-school children's development. There are varied reasons that result in unsuccessful preparation of a child for school. They may embrace absence of appropriate conditions for education at home, pedagogical neglect (social character-determined reasons), disorders of physical and mental development (biological reasons), conflict situations that result in psychological traumas (psychological reasons), etc. It is important to identify if the immaturity for school is of temporary character and may be overcome or are there any stable reasons (e.g., intellectual disorder). The purpose of pre-primary education is to assist a child in successful preparation for learning according to primary education curriculum and it is carried out in compliance with the general curriculum of pre-primary education, which lasts for one year and is approved by the Minister of Education and Science. Pre-primary education is implemented by pre-school education institutions, schools of general education, free teachers or other providers of education in accordance with the order approved by the Minister of Education and Science. A child is entitled to pre-primary education services on the calendar year, when a child reaches 6 years of age. Pre-primary education may be provided earlier under request of parents (caregivers) following the Descriptor of Procedure for Evaluation of Child's Maturity to Learn According to Pre-primary and Pre-school Curricular but not earlier than a child reaches 5 years of age. In cases and according to the procedure established by the Minister of Education and Science and the Minister of Social Security and Labour, pre-primary education may be obligatory. A pre-primary child and his / her parents (caregivers) are provided with complex educational support, social support, health care following the order approved by the Minister of Education and Science and the Minister of Social Security and Labour (The Order of the Minister of Education and Science of Republic of Lithuania, p. 7-8). It can be stated that legislation for assurance of child's maturity for school is sufficient in the Republic of Lithuania. The necessary level of maturity for school may be achieved only educating a child in a pre-school education institution. Therefore, attempts of the Ministry of Education and Science to introduce mandatory pre-school education in the country are welcome.

The pre-school children's maturity for school has been investigated by Lithuanian (Adaškevičienè, 1993; Ambrukaitis, 1997; Jankauskienè, Šeibokienė, 2003; Bortkevičienè, 1999; Meškauskaitė, 2005; Grinienè, Kasputienè, 2009; Monkevičienè, Glebuvienè, 2011) as well as foreign researchers (Brewer, 1995; Harris, 1991; Santrock, 1998; Wenger, 1994; 
Vygotsy, 200; Podlas, 2005). Psychologist Alfonsas Gučas (1907-1988) and educator Jonas Laužikas (1903 - 1980) were the first to focus on children's school maturity in Lithuania (Gudonis, Ališauskas, 1996; Jankauskienè, Monkevičienè, Šeibokienè, 2002). The data of international comparative research, whereof sample included 51144 pre-school children from 13 countries, were published in the last decade of the previous century (Santrock, 1995). The research proved that only pre-school education institutions may properly prepare children for school. The specialists from the Department of Childhood Studies of Lithuanian University of Educational Sciences have been carrying out research on problems of pre-school-children's maturity for school since 1997. In the academic year 2001 - 2002 V. Glebuvienè, B. Grigaite, O. Monkevičienè, K. Stankevičienè, A. Tarasonienè and 14 Master programme students conducted research on preparation of 2801 st formers from various Lithuanian schools, which again confirmed the necessity for pre-school education (Gintilienè, Butkienè, Girdzijauskienè, Dragūnevičienè, Gudauskienè, 2005). The scope and volume of research on school maturity of children with special learning needs have been narrow in Lithuania: only the data on children with hearing (Poglazova, 2002) and visual impairments (Grinienè, Kasputienè, 2009) are available, whereas the descriptions of the longitudinal research on school maturity of pre-primary children with visual impairments have not been identified in scientific literature sources.

The object of the research: school maturity of pre-primary children with visual impairments.

The goal of the research: to identify school maturity of pre-primary children with visual impairments as a relevant prerequisite for socialisation.

The methods of the research: The Methodology for Assessment of Children's Maturity for School (developers of methodology G. Gintilienè, D. Butkienè, S. Girdzijauskienè, R. Dragunevičienè, V. Gudauskienè, 2005) were used: Strengths and Difficulties Questionnaire (R. Goodman, 1997, 2001); Coloured Progressive Matrices, (D. K. Raven, I. Stail, M. Raven, 2004); Auditory Perception Task, (L. Palačionienè, G. Gintilienè, V. Gudaitytè, V. Gudauskienè, 2005); Copying of a Human Being Drawing ( G. Gintilienè, D. Butkiené, S. Girdzijauskienè, V. Gudauskienè, 2005); Vocabulary Scales( G. Gintilienè, D. Butkiené, S. Girdzijauskiene, V. Gudaitytè, V. Gudauskiene, 2005); Descriptor of Child's Problematic Behaviour ( G. Gintilienè, S. Girdzijauskienè, V. Gudaitytè, V. Gudauskienè, 2005; conversation with a child; conversation with parents; Kern's test of school maturity with Jirásek's modification.

The sample of the research: 310 pre-primary children with visual impairments from Petras Avižonis Vision Centre of Šiauliai. The average age of children - 6.3 years, visual acuity V 0.3-1.

The procedure of the research: the data acquired during the research conducted on school maturity of pre-primary children with visual impairments from Avižonis Vision Centre of Šiauliai carried out from 2003 to 2013. 
Striving for better knowledge and understanding of a child, a pre-primary teacher observes him or her according to the need, applies other methods of cognition making attempts to clarify child's well being, needs, interests, level of various skills, peculiarities of communication and activities, cultural environment at home, family expectations and attitudes to education. A teacher is able to ensure timely identification of child's behavioural problems, obvious lack of skills and experiences, to recognise special learning needs. On the basis of the accumulated material on child's cognition, a teacher individualises education, chooses forms of motivating, corrective, rehabilitative and therapeutic education and, if necessary, ensures provision of specialists' help. Collaborating with parents, a pre-primary educator evaluates child's achievements on the basis of the indicators of 'Child's Maturity for School' and 'The Standard of Pre-primary Education' in autumn and spring. The goal of achievement assessment in the beginning of the school year is to foresee further directions for child's further (self-)education, to design an individual programme of education for a child or a group, to correct process of education taking into account the real abilities of a child and striving for his / her optimal school maturity. The assessment at the end of the school year is conducted to identify each child's individual progress and to inform the parents and a future teacher (The General Curriculum Framework for Pre-Primary Education and Self-Education, 2002). In Petras Avižonis Vision Centre of Šiauliai a psychologist realises the provisions outlined in the General Curriculum Framework for Pre-Primary Education and Self-Education, who on the basis of research data, prepares individual recommendations for educators (teachers, parents, caregivers).

\section{The results of the longitudinal research}

A child with visual impairments perceives own exceptionality very early: s/he has to wear glasses, one eye is frequent covered (in case of amblyopia) and their sight is weaker. This negative exceptionality may reduce self-esteem, impede adaptation in a group of peers and in new environment. Due to lower self-esteem and challenged adaptation, there emerges shyness, which suppresses child's activity and initiative. Such children have more emotional and behavioral problems. They more frequently suffer from mood changes, attention and activity disorders as well as from problems related to communication with peers and adults. Avoiding social contacts, children fail to acquire or obtain only poor social skills. Weaker psychical health of children with visual impairments prevents such children from achieving the maturity level necessary for school and, simultaneously, slows down the process of their socialisation. Traditionally the children's maturity for school was researched before their leaving the educational institution. Having established a low level of maturity, it was impossible to correct it as a child was leaving the institution. To improve this situation, the maturity for school of pre-primary children 
has been investigated in Petras Avižonis Vision Centre in Šiauliai twice per year since 2005 (see: Fig. 1, 2 and 3: the first research was carried out in September and the second one was carried out in May).

On the basis of the results of the first research, a psychologist prepared recommendations to each child's parents and group teachers. As a result, children's maturity for school underwent considerable changes (see: Table 1 and Fig. 1, 2 and 3).

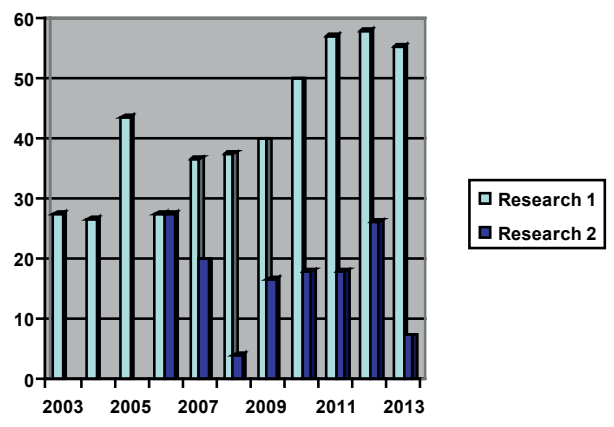

Fig. 1. Dynamics of low level of maturity for school among learners in pre-primary groups (\%)

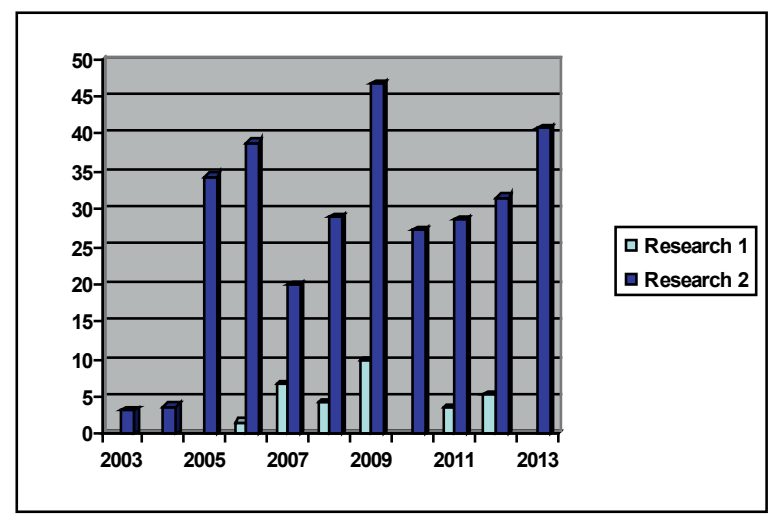

Fig. 2. Dynamics of average level of maturity for school among learners in pre-primary groups (\%) 


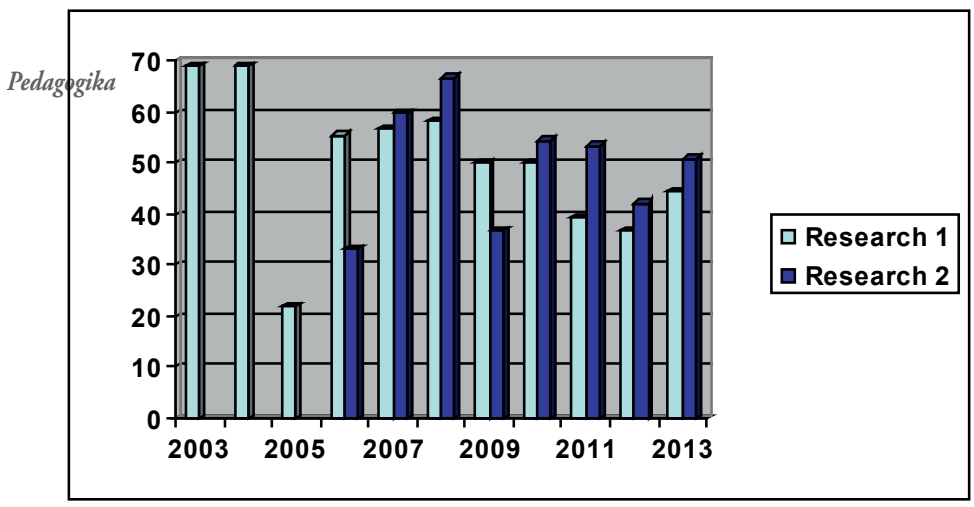

Fig. 3. Dynamics of high level of maturity for school among learners in pre-primary groups (\%)

The results of the longitudinal research carried out from 2003 to 2013 showed that from 30 to $50 \%$ of children, who start attending pre-primary groups in Petras Avižonis Vision Centre in Šiauliai, demonstrate a low level of school maturity. The gradually increasing numbers of children with low level of maturity for school have been raising deep concern: from $27 \%$ in 2003 to 55 \% in 2013, i.e., a twofold growth was identified. This negative tendency may be explained by gradually decreasing volume of attention and time allocated to children's socialisation by parents. Underestimating the importance of communication with a child, parents spend less and less time communicating with their children. One more circumstance, which impedes child's socialisation, is linked to the fact that a number of children do not have any brothers and sisters, what increases deficit of communication. Children's socialisation is also predetermined by the fact that children live in incomplete families. Some mothers are divorced with their husbands, a number of other fathers work abroad. Several children, who took part in the research, live with their grandparents as their parents work abroad. In a traditional Lithuanian family grandparents most frequently live separately from their children, therefore, their communication with grandchildren is rather episodic. At home children usually draw, play board and computer games or watch television. Due to all the aforesaid circumstances, a pre-school child experiences deficit of communication both with adults and peers in home environment, what has a negative effect on his/her school maturity and socialisation.

The main problems of children's development identified after the first research on children's maturity for school are as follows:

1. problems of concentration and retention of attention.

2. problems of comparison of objects (finding of similarities and differences of objects following sensor standards of size, form and colour), their grouping and classification.

3. underdeveloped visual-motor coordination.

4. weak attitudes towards becoming a learner. 


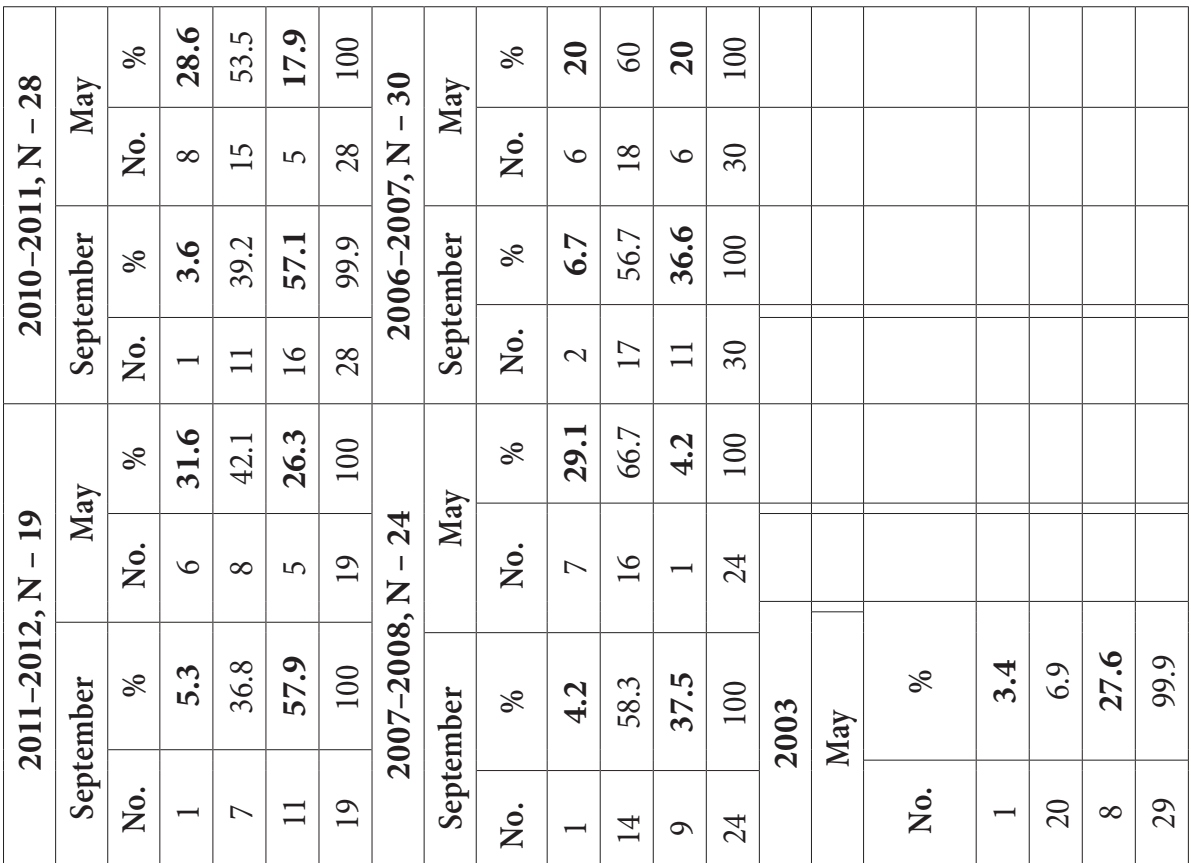

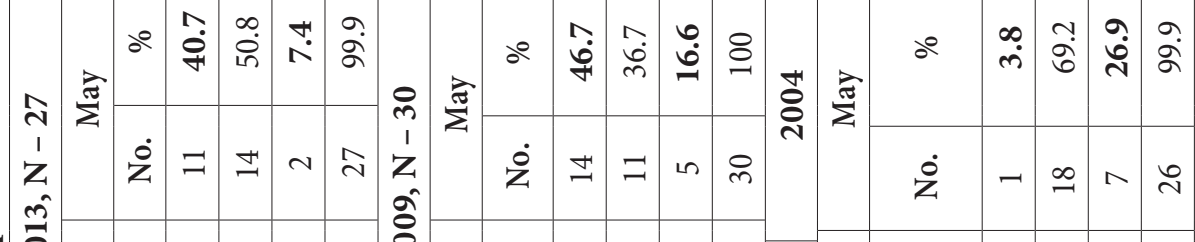

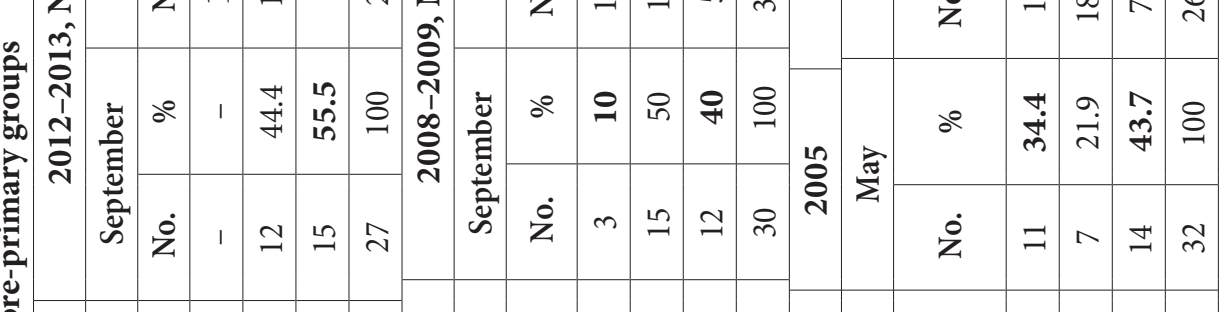

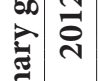

产

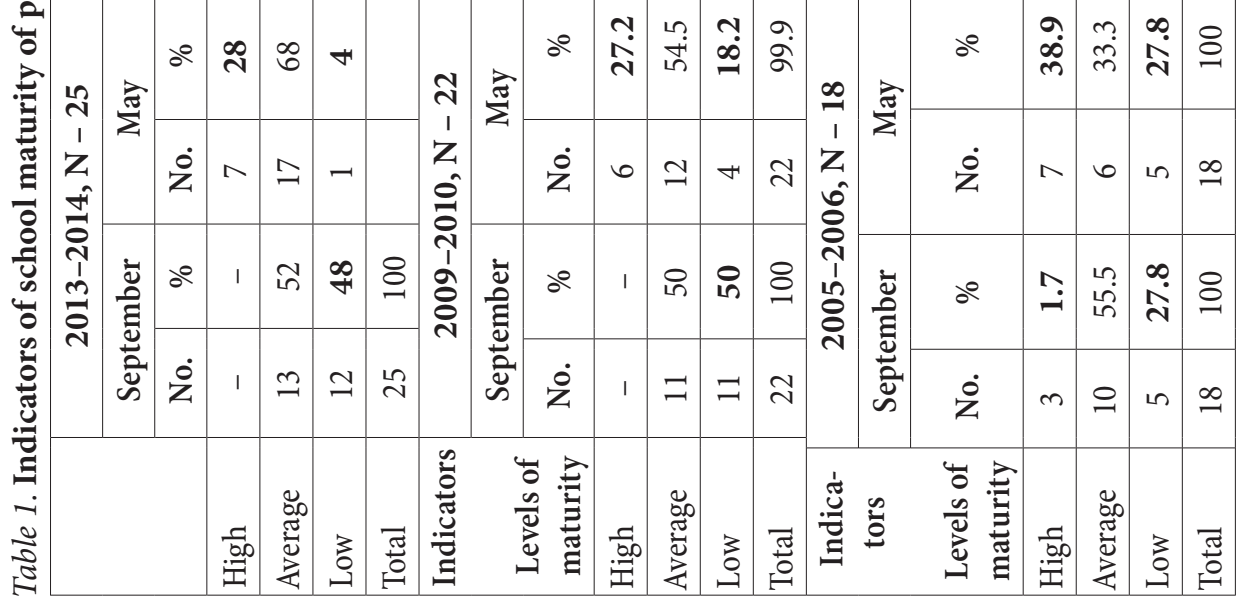


It can be concluded that weak visual-motor coordination may be more or less determined by visual impairments. Other reasons for the aforesaid problems may be explained through insufficient attention of educators (teachers and parents) to problems of comparison of objects (finding of similarities and differences of objects following sensor standards of size, form and colour), their grouping and classification as well as to development of socially significant motives to learn at school.

Children with the established low level of maturity for school were hardly able to follow instructions of adults: children start carrying out instructions related to manner of doing ("how to do") later and face more difficulties doing that compared to instruction related to outcome of an action ("what to do").

No considerable changes were observed in the group with the average level of maturity for school because in the autumn research a group of children with the same level of maturity was identified. Some learners entered this group from the low level and a number of children left this group for the one of higher level. Thus, this group may be referred to as a transitional one.

The data of the research showed that during the first research conducted in September we sometimes failed to find at least one child with high school maturity. During the first survey the biggest number of such children was observed in 2009, when this group consisted of about $10 \%$ of children, whereas after working with children according to the individual programme over $40 \%$ of pre-primary learners in 2013 demonstrated high school maturity. Fast and positive dynamics of school maturity is evidenced by increased indicators of high school maturity. From 2003 to 2005, when children's school maturity was investigated only one a year, about one third of children $(32.7 \%)$ started school with low school maturity indicators, whereas $13.9 \%$ of children were highly mature for school. Introduction of two surveys of children per year and individual recommendations resulted in a decrease in the numbers of children with low maturity level to $11.9 \%$, i.e., this indicator went down almost three times and the numbers of children with high maturity for school rose to $28.9 \%$, i.e., a twofold increase was observed. A significantly increased number of pre-primary group attendees, who achieved high level of maturity for school, justifies our chosen educational strategy to conduct research on school maturity of children in this age group two times a year and to prepare individual recommendations to learners.

\section{Conclusions}

- School maturity of pre-school children is an important prerequisite for child's socialisation.

- Pre-school children with visual impairments, who attend pre-school education institutions, may be properly prepared for school. 
- Positive working experience acquired in Petras Avižonis Vision Centre in Šiauliai reveals that pursuing proper preparation of children for school, it is recommended to psychologists to carry out research on school maturity of pre-primary children twice a year (autumn and spring) and to prepare individual recommendations to educators (teachers, parents, caregivers) after the first research.

\section{References}

Adaškevičienè, E. (1993). Lietuvos ikimokyklinuku fizinis ugdymas. Kaunas: Šviesa, 204 p.

A Review of Services for Young Children in the European Union 1990-1995. European Commission Network on Childcare and other Measures to reconcile Employment and Family Responsibilities. January 1996.

Ankstyvojo ir ikimokyklinio amžiaus specialiuju poreikiu vaikų ugdymas. (1997). Compiler J. Ambrukaitis. Šiauliai, 87p.

Bagdonienè, J., Stundienė, D., Žalaitė, Z. and others. (2003). Ar pažǐstate šešiametị. In Priešmokyklinis ugdymas: collection of articles. Compil. L. Jankauskienè, G. Šeibokienè. Vilnius, 29-35.

Bendroji priešmokyklinio ugdymo ir ugdymosi programa. (2002). The authors of the curriculum: O. Monkevičienè (head of group), V. Bartkevičienè, V., Glebuvienė and others. Vilnius: ŠMM, Švietimo aprūpinimo centras.

Bendrosios programos ir išsilavinimo standartai. Priešmokyklinis, pradinis ir pagrindinis ugdymas. (2003). Švietimo ir mokslo ministerijos Švietimo plètotès centras. Vilnius, 63 p.

Berns, R. M. (2009). Vaiko socializacija: šeima, mokykla, visuomené. Kaunas: Poligrafija ir informatika.

Bortkevičienė, V. (1999). Šešiamečių brandumas mokyklai. In The proceedings of the jubilee conference 'Lithuanian Kindergarten: the Past and Future'. Vilnius.

Brewer J. (1995). Early Childhood Education. Preschool Through Primary Grades. Allyn and Bacon, Boston, London, $507 \mathrm{p}$.

Bukmanaite, A. (2003). Priešmokyklinio ugdymo organizavimas Kaune. In Priešmokyklinis ugdymas: collection of articles / Ministry of Education and Science of Republic of Lithuania. Compilers L. Jankauskienè, G. Šeibokienè. Vilnius, 6-10.

Gintilienè, G., Butkienè, D., Girdzijauskienè, S., Dragūnevičienė, R., Gudauskienė, V. (2005). Vaikų brandumo mokyklai įvertinimo metodika. Vilnius.

Glebuvienè, V. (1999). Rašytinè kalba. Kada ir kaip vaikas jos mokosi. In The proceedings of the jubilee conference 'Lithuanian Kindergarten: the Past and Future'. Vilnius, 92-98.

Glebuviene, V., Grigaite, B., Monkevičienè, O. (2002). Lietuvos vaiku brandumo mokyklai tyrimo moksline ataskaita. Vilnius.

Glebuvienè, V., Grigaitė, B., Monkevičienè, O. (2004). Lietuvos vaikų brandumo mokyklai: tyrimas ir problemos. Vilnius: VPU. 
Grigaite, B. (1996). Vaikų protinio brandumo mokyklai tyrimas. In Mokymo ir auklejimo klausimai. XXVII. Vilnius, 158-160.

Grigaite, B. (1998). Vaiku brandumo mokyklai klausimai. In The proceedings of the conference 'Lithuanian Psychology in the Turn of Centuries' to commemorate the $90^{\text {th }}$ Anniversary of A. Gučas. Vilnius, 96-100.

Grinienė, E., Kasputienè, Ž. (2009). 6-7 metų vaikų smulkiosios motorikos įtaka jų parengtumui mokyklai. Sporto mokslas, 4. 50-56.

Gučas, A. (1999). Vaikų sambranda mokykliniam darbui. In Psichologai apie žmogaus raidą. Kaunas, 203-212.

Gudonis, V., Ališauskas, A. (1996). Aukšto lygio mokyklinė branda - sèkmingo pradinių klasių mokinių mokymosi garantas. In Pradinis mokymas: retrospektyva ir perspektyva. Proceedings of scientific conference. Šiauliai, 84-87.

Harris, J. R., Liebert, R. M. (1991). The Child. A Contemporary View of Development. Prentice Hall, Englewood Cliffs, New Jersey, 586 p.

Kvieskienė, G. (2005). Pozityvioji socializacija. Vilnius:VPU leidykla.

Laužikas, J. (1999). Mokyklinès sambrandos pagrindai. In Psichologai apie žmogaus raidą. Kaunas, 163-168.

Lukoševičius, A., Petružienè, S. (2001). Priešmokyklinio amžiaus vaikų vystimosi ypatumai miesto ir kaimo sąlygomis. Pedagogika, 53, 77-80.

Meškauskaite, E. (2005). Sutrikusios regos vaikų pažintinis brandumas mokyklai integruoto ugdymo sallygomis: master paper. VPU [accessed 6 February 2014]. Available at: www.svetdetstva.ru/ shkolnaga-rrelost.

Monkevičienè, O., Glebuvienè, V. S. (2011). Metodinis leidinys priešmokyklinio ugdymo pedagogams. Vilnius.

Priešmokyklinis ugdymas. Book 1. (2002). L. Jankauskienė, O. Monkevičienė, G. Šeibokienė (Compil.). Vilnius.

Raubienè, V., Norkuvienè, Ž. (2014). Mokyklos link. Vakarų ekspresas. 6 February 2014 [accessed 6 February 2014]. Available at: www.velt/naujienos/visuomenè/psichologija/

Santrock, J. W. (1995). Children. Brown and Benchmark publishers, Madison, Wisconsin (655 p.). The Future of Children. Winter 1995, 5, 3. The Center for the Future of Children. The David and Lucile Packard Foundation [accessed 14 February 2014]. Available at: http://futureofchildren. org/futureofchildren/publications/docs/08_01_.

Santrock, J. W. (1998). Child Development. Mc Graw Hill, Boston, Massachusetts Bur Ridge, 692 p. The Law on Education of the Republic of Lithuania No. XI-1281 of 17 March 2011 [accessed 6 February 2014]. Available at: http://www.mprc.lt/file/svietimo\%20istatymas/Svietimo\%20 istatymas_2011.pdf.

The Order of the Minister of Education and Science of Republic of Lithuania No. ISAK-1156 of 30 October 1996 [accessed 6 February 2014]. Available at: https://www.google.lt/\#q=LR+\%C 5\%A0vietimo+ir+mokslo+ministro+.+\%C4\%AFsakymas+No.+\%C4\%AESAK-1156 
The Order of the Minister of Education and Science of Republic of Lithuania No. ISAK-1180 of 22 June 2005 [accessed 6 February 2014]. Available at: http://www.siauliai.lt/svietimas/ priesm_organizavimo_aprasas.pdf.

The Order of the Minister of Education and Science of Republic of Lithuania No. ISAK-2173 of 29 October 2005 [accessed 6 February 2014]. Available at: http://www.google.lt/\#q=LR+\%C $5 \%$ A0vietimo+ir+mokslo+ministro+2005+m.+spalio+29+d.+\%C4\%AESAKYMAS+No.+\% C4\%AESAK-2173.

The Order of the Minister of Education and Science of Republic of Lithuania No. ISAK-1836 of 14 September 2007 [accessed 6 February 2014]. Available at: http://www.moletusaulute.lt/ wp-content/uploads/2013/12/ISAK-1836.pdf.

Varnienè, E. (2014). Apie mokyklinę branda [accessed 6 February 2014]. Available at: www. pavilnioziogelis.lt/index.php/straipsniai/109-brandas.html.

Акшенцева, Ю. О. (2011). Психологическая диагностика школьной зрелости детей (на материале методики И. Ирасека). Проблемы современного образования, 1, 94-97.

Венгер, Л. А., Марциновская, Т. Д., Венгер, А., Л. (1994). Готов ли Ваш ребенок к школе? Москва.

Выготсий, Л. С. (2000). Психология. Москва: Эксмо-Пресс.

Поглазова, О. Т. (2002). Курс лекций по коррекиионной педагогике. Для средних специальных учебных заведений. Москва: Владос.

Подласый, И. П. (2005). Готовность к школе. Методические рекомендации к учебному пособию «Вместе со сказкой». Москва: XXI век.

Речицкая, Е. Г., Пархалина, Е. В. (2003). Готовность слабослышащих детей дошкольного возраста к обучению в школе. Москва: Владос.

Чепуленене, Ю. (2010). Убеждение родителей о школьной зрелости ребенка. In Daugavpils Universitates 52: starptautiskas zinatniskas konferences tezes - abstract of the 52nd International Scientific Conference of Daugavpils University (pp. 121-122). Daugavpils: Daugavpils University. 


\title{
Priešmokyklinio amžiaus vaikų, turinčių regos sutrikimų, mokyklinè branda kaip sẻkmingos socializacijos prielaida
}

\author{
Vytautas Gudonis ${ }^{1}$, Audrè Urbiené ${ }^{2}$ \\ 1 Šiaulių universitetas, Socialinès gerovès ir negalès studijų fakultetas, Specialiosios pedagogikos katedra, \\ P. Višinskio g. 25, 76351 Šiauliai, vytautas.gudonis@su.lt \\ 2 Šiaulių Petro Avižonio regos centras, Papilès g. 3, 76196 Šiauliai
}

\section{Santrauka}

Straipsnyje pateikiami priešmokyklinio amžiaus vaikų, turinčių regèjimo sutrikimų, mokyklinès brandos 2003-2013 m. ilgalaikio tyrimo rezultatai. Remiantis daugiamečių tyrimų rezultatais nustatytos priešmokyklinio amžiaus vaikų, turinčių regėjimo sutrikimų, ugdymo problemos, determinuotos regejjimo sutrikimų bei nepakankamo ugdytojų dèmesio. Straipsnyje siekiama atskleisti mokyklinès brandos turinị ir, remiantis gautais tyrimo rezultatais, ̨̣rodyti būtinumą priešmokyklinių grupių vaikų, lankančių ugdymo įstaigas, mokyklinę brandą tirti du kartus per metus, po pirmojo tyrimo parengiant jiems individualias rekomendacijas.

Tyrimo tikslas - nustatyti priešmokyklinio amžiaus vaikų, turinčių regos sutrikimų, mokyklinę brandą, kaip svarbią socializacijos prielaidą.

Tyrimo metodika. Tyrimui buvo panaudota „Vaikų brandumo mokyklai ịvertinimo metodika" (metodikos rengèjai G. Gintilienè, D. Butkienè, S. Girdzijauskienè, R. Dragunevičienè, V. Gudauskienè, 2005): Galių ir sunkumų klausimynas tèvams ir auklètojams (R. Goodman, 1997, 2001); Spalvotos sudètingèjančios matricos (D. K. Raven, I. Stail, M. Raven, 2004); Girdimojo suvokimo užduotys (L. Palačionienè, G. Gintilienè, V. Gudaitytè, V. Gudauskienè, 2005); Žmogaus piešinio kopijavimas (G. Gintilienè, D. Butkienė, S. Girdzijauskienè, V. Gudauskienè, 2005); Žodyno skale (G. Gintilienè, D. Butkienè, S. Girdzijauskienè, V. Gudaitytè, V. Gudauskienė, 2005); Vaiko probleminio elgesio aprašas (G. Gintilienè, S. Girdzijauskienè, V. Gudaitytè, V. Gudauskienè, 2005); Pokalbis su vaiku; Pokalbis su tèvais; J. Jiraseko modifikuotas A. Kerno testas.

Tiriamieji - 310 Šiaulių Petro Avižonio regos centro priešmokyklinio amžiaus vaikų, turinčių regos sutrikimų. Tiriamųjų amžiaus vidurkis - 6,3 m., regos aštrumas V 0.3-1. Tyrimo eiga: tyrimui panaudoti 2003-2013 m. Šiaulių Petro Avižonio regos centro priešmokyklinio amžiaus vaikų, turinčių regos sutrikimų, mūsų atlikto mokyklinès brandos tyrimo duomenys.

Išvados. Ikimokyklinio amžiaus vaikų mokyklinė branda yra svarbi vaiko socializacijos prielaida. Ikimokyklinio amžiaus vaikai, turintys regos sutrikimų ir lankantys ikimokyklinio ugdymo ịstaigas, gali būti tinkamai parengiami mokyklai. Teigiama 
darbo patirtis Šiaulių Petro Avižonio regos centre rodo, kad siekiant tinkamai parengti ugdytinius mokyklai, ikimokyklinėse ugdymo įstaigose psichologui rekomenduotina priešmokyklinių grupių vaikų mokyklinę brandą tirti du kartus per metus (rudenį ir pavasarį) ir po pirmojo tyrimo parengti ugdytojams (pedagogams, tėvams, globejjams) individualias rekomendacijas.

Esminiai žodžiai: priešmokyklinio amžiaus vaikai, mokyklinè branda, regèjimo sutrikimas.

Itteikta / Received 2014-09-05

Priimta / Accepted 2014-10-12 